\title{
Quantum Chemical Computational Studies on 4-(1-Aminoethyl)pyridine
}

\author{
Hatice VURAL ${ }^{1 *}$ \\ ${ }^{1}$ Amasya University, Department of Electrical and Electronics Engineering, 05000, Amasya
}

Geliş / Received: 30/03/2021, Kabul / Accepted: 05/07/2021

\begin{abstract}
The density functional theory (DFT) method combined with B3LYP and B3PW91 hybrid functional were utilized for geometrical optimization, vibrational frequencies and electronic spectral study. The B3LYP and B3PW91 levels of the time dependent-DFT with $6-311+\mathrm{G}(\mathrm{d}, \mathrm{p})$ basis set have been used to determine the highest occupied molecular orbital (HOMO) - the lowest unoccupied molecular orbital (LUMO) energies, absorption wavelengths, and electronic properties (total energy and energy gap) of 4-(1-aminoethyl)pyridine. Global reactivity descriptors like ionization potential, chemical hardness and electron affinity, etc. have been estimated using the B3LYP/6-311+G (d, p) and B3PW91/6-311+G (d, p) methods. The effect of the solvent has been simulated using the integral equation formalism-polarized continuum model (IEF-PCM).
\end{abstract}

Keywords: DFT, Energy, 4-(1-aminoethyl)pyridine, Solvent effect

\section{4-(1-Aminoetil)piridin’in Kuantum Kimyasal Hesaplamaları Üzerine Çalışmalar}

$\ddot{O} \mathbf{z}$

Geometrik optimizasyonu, titreşim frekansları ve elektronik spektral çalışma için yoğunluk fonksiyonel teorisinin (DFT) B3LYP ve B3PW91 hibrit fonksiyonelleri kullanıld1. 4-(1-aminoetil) piridin'in en yüksek dolu moleküler orbital (HOMO) ve en düşük boş moleküler orbitallerin (LUMO) enerjileri, absorbsiyon dalga boylarının ve elektronik özelliklerinin (toplam enerji, enerji aralığı vb.) hesaplanmasında zamana bağlı-DFT ile B3LYP ve B3PW91 ve 6-311+G(d, p) baz seti kullanıld1. İyonizasyon potansiyeli, kimyasal sertlik ve elektron afinitesi gibi global reaktiflik tanımlayıcıları B3LYP/6-311+G (d, p) ve B3PW91/6-311+G (d, p) yöntemleri kullanılarak tahmin edilmiştir. Çözücü etkisi zamana bağlı yoğunluk fonksiyonel teorisine sürekli polarizasyon modeli (IEF-PCM) uygulanarak hesaplandı.

Anahtar Kelimeler: DFT, enerji, 4-(1-aminoetil)piridin, çözücü etkisi

\section{Introduction}

Cancer is one of the biggest health problems from past to present (Sankpal et al., 2012). The high toxicity of chemotherapeutic drugs used in the treatment and the resistance of various tumor cells to anticancer drugs pose a critical medical problem (Szakacs et al., 2006). Although the development of new and effective cancer treatments is the most important goal, new drug design and tests are of great importance. DNA has become one of the main biological targets for antitumor compounds since the development of cisplatin, the most important cancer drug (Huang et al., 2005; Pizarro et.al., 2009). Therefore, the experimental and computational study of the interaction of appropriate molecules with DNA is of great importance in drug design.

\footnotetext{
*Corresponding Author: hatice.vural@ amasya.edu.tr
} 
Pyridine and its derivatives are preferred in the synthesis of different compounds because they have many pharmacological properties such as antimicrobial (Bhatt et al., 2001), antifungal (Patrick et al., 1996; Hishmat et al.,1990), and antitubercular (Doshi et al.,1999). Aminopyridines have attracted attention to the account of their potential uses in different fields, particularly in the treatment of neurologic disorders (Strupp et al., 2017). It is known that especially 4-aminopyridine (4-AP) and 3,4-diaminopyridine (3.4-DAP) are used in the treatment of diseases such as ocular motor disorders (Smith et al.,1994; Middleton et al.,1980; Dubey et al.,2010; Sedehizadeh et al., 2012; Keogh et al.,2011).

In the previous study, the coordination polymers including 4-(2-aminoethyl)pyridine were synthesized and characterized with XRD method, FTIR and Raman techniques by Karaağaç et al. (Karaağaç et al., 2019). They have also reported the FT-IR and Raman spectral data, the thermal properties and the crystal structures of some metal(II) tetracyanometalatte(II) complexes with 4-(2- aminoethyl)pyridine (Karaağaç et al. 2017). Although studies on 4-(2aminoethyl)pyridine are limited in the literature, there is no studies on 4-(1aminoethyl)pyridine.

Preferring computational methods to investigate many new properties while working on a molecule provides a great advantage in terms of time and cost. DFT has been increasingly used for calculating a wide variety of molecular properties that includes stability structure, charge transfer interactions, transition states, etc. DFT computations have made a significant contribution to the understanding of the quantum chemical properties of 4-(1aminoethyl)pyridine.

Up to now, there are no theoretical and experimental studies of 4-(1-aminoethyl)pyridine in the literature. The optimized geometric parameters and vibrational frequencies have been calculated using B3LYP and B3PW91 with 6-311+G $(\mathrm{d}, \mathrm{p})$ basis set. Therefore, in this work, the ionization potential $(I)$, electron affinity $(A)$, electronegativity $(\chi)$, chemical hardness $(\eta)$, softness (s), and electrophilic index ( $w$ ) have been investigated for 4-(1-aminoethyl)pyridine. The indicator used in the computational bio-activity study of the molecule is the electrophilic index. In addition, the toxic potential of substances can be estimated by calculating the electrophilic index (Siddiqui and Javed, 2021). The electronic excitation energy and absorption wavelengths of 4-(1-aminoethyl)pyridine have been computed by using the B3LYP and B3PW91 methods with the 6-311+G (d, p) basis set. The electronic absorption spectra of 4-(1aminoethyl)pyridine have been calculated by using DFT two different methods in water. The effect of the solvent has been simulated using the integral equation formalism-polarized continuum model (IEF-PCM).

\section{Computational Details}

The geometry of 4-(1-aminoethyl)pyridine molecule has been optimized by using the B3LYP (Lee et al., 1988), and B3PW91 (Perdew et al., 1996) levels of the density functional theory (DFT). The quantum chemical descriptors were calculated using GAUSSIAN 09W program packages (Frisch et al., 2009). The Gauss View 5.0 program was used to generate visual presentations (Dennington, 2009). The electronic spectral parameters of 4-(1aminoethyl)pyridine in water and the gas phase were investigated by using DFT (B3LYP and B3PW91) method with the 6-311+G (d, p) basis set. The B3LYP and B3PW91 hybrid functional with $6-311+\mathrm{G}(\mathrm{d}, \mathrm{p})$ basis set were also used to calculate the chemical hardness, softness, and electronegativity. 


\section{Results and Discussion}

\subsection{Geometry optimization}

The optimized geometry of 4-(1-aminoethyl)pyridine was carried out using the B3LYP and B3PW91 levels combined with 6-311+G(d, p) basis set (Fig. 1) The selected parameters of 4(1-aminoethyl)pyridine for the two-hybrid functionals are tabulated in Table 1.

The geometric parameters (bond lengths and angles) of 4-(1-aminoethyl)pyridine are calculated slightly differently from the B3LYP method by the B3PW91 method. The C4-C7, C7-C8, and C7-N2 bond lengths are computed as $1,525 \AA, 1,542 \AA$, and 1,467 for the B3LYP level,

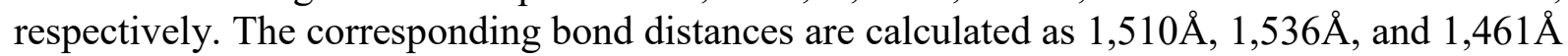
for the B3PW91 level, respectively.

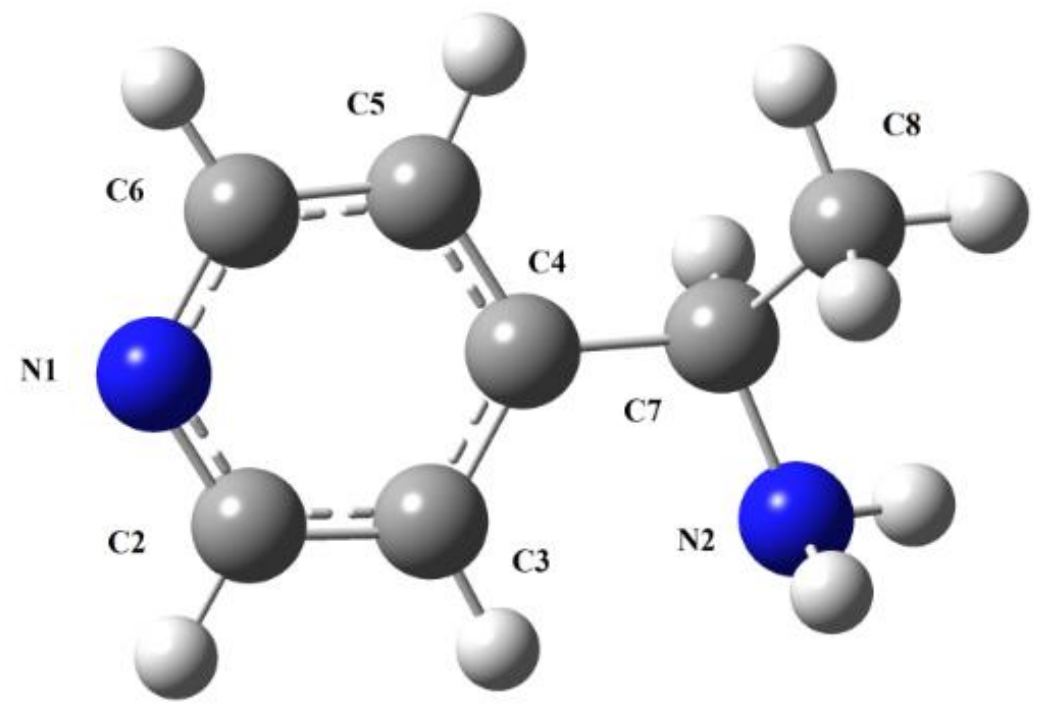

Figure 1. The optimized (with B3LYP/6-311+G (d, p) level) geometric structure of 4-(1aminoethyl)pyridine.

The angle $\mathrm{C} 4 / \mathrm{C} 7 / \mathrm{C} 8$ is predicted as $111,62^{\circ}$ for B3LYP hybrid functional and $111,72^{\circ}$ for B3PW91 hybrid functional. The $\mathrm{C} 4 / \mathrm{C} 7 / \mathrm{N} 2$ angle is calculated as $111,07^{\circ}$ for the DFT/B3LYP method, while the angle is computed as $110,89^{\circ}$ for the DFT/B3PW91 method. 
Table 1. Selected molecular structure parameters

\begin{tabular}{|c|c|c|}
\hline & B3LYP & B3PW91 \\
\hline \multicolumn{3}{|c|}{ Bond Lengths( $(\AA)$} \\
\hline $\mathrm{N} 1-\mathrm{C} 2$ & 1,334 & 1,332 \\
\hline $\mathrm{N} 1-\mathrm{C} 6$ & 1,337 & 1,334 \\
\hline $\mathrm{C} 2-\mathrm{C} 3$ & 1,397 & 1,392 \\
\hline $\mathrm{C} 3-\mathrm{C} 4$ & 1,395 & 1,393 \\
\hline $\mathrm{C} 4-\mathrm{C} 5$ & 1,399 & 1,397 \\
\hline $\mathrm{C} 5-\mathrm{C} 6$ & 1,390 & 1,389 \\
\hline $\mathrm{C} 4-\mathrm{C} 7$ & 1,525 & 1,520 \\
\hline $\mathrm{C} 7-\mathrm{C} 8$ & 1,542 & 1,536 \\
\hline $\mathrm{C} 7-\mathrm{N} 2$ & 1,467 & 1,461 \\
\hline \multicolumn{3}{|l|}{ Angles $\left(^{\circ}\right)$} \\
\hline $\mathrm{C} 4-\mathrm{C} 7-\mathrm{C} 8$ & 111,62 & 111,72 \\
\hline $\mathrm{C} 4-\mathrm{C} 7-\mathrm{N} 2$ & 111,07 & 110,89 \\
\hline $\mathrm{C} 5-\mathrm{C} 4-\mathrm{C} 7$ & 120,88 & 121,17 \\
\hline $\mathrm{C} 3-\mathrm{C} 4-\mathrm{C} 7$ & 122,44 & 122,15 \\
\hline
\end{tabular}

\subsection{IR Assignment}

The calculated IR spectra of 4-(1-aminoethyl)pyridine was carried out using the DFT/B3LYP and DFT/B3PW91 level with 6-311+G $(\mathrm{d}, \mathrm{p})$ basis set. The theoretical data of vibration frequencies are tabulated in Table 2, as compared with experimental results (Karaağaç et al., 2017). The FT-IR spectra are displayed in Fig. 2. The computed frequencies are scaled with 0.96 for B3LYP and 0.95 for B3PW91 (Merrich et al., 2007; Sundaraganesan et al., 2005). Since there is no theoretical and experimental vibration frequencies so far in the literature of 4(1-aminoethyl)pyridine, the vibration frequencies of 4-(2-aminoethyl)pyridine (4aepy) (Karaağaç et al., 2017) for vibration frequencies of 4-(1-aminoethyl)pyridine are used. Karaağaç et al. (2017) have reported $\mathrm{NH}_{2}$ asymmetric and symmetric stretching frequencies of 4aepy molecule are found as $3362 \mathrm{~cm}^{-1}$ and $3292 \mathrm{~cm}^{-1}$. The corresponding stretching frequencies are calculated as $3432-3349 \mathrm{~cm}^{-1}$ for B3LYP, and $3420-3334 \mathrm{~cm}^{-1}$ for B3PW91 levels. The in-plane $\mathrm{NH}_{2}$ bending vibration of 4aepy molecule is observed at $1605 \mathrm{~cm}^{-1}$ experimentally and calculated at $1595 \mathrm{~cm}^{-1}$ for DFT/ B3LYP and $1575 \mathrm{~cm}^{-1}$ for DFT/ B3PW91.

The CH stretching mode of 4aepy molecule appears at $3072 \mathrm{~cm}^{-1}$ experimentally (Karaağaç et al., 2017). The computed vibrations at $3077 \mathrm{~cm}^{-1}$ and $3053 \mathrm{~cm}^{-1}$ are assigned to $v(\mathrm{CH})$ mode for B3LYP and B3PW91 levels. The $v\left(\mathrm{CH}_{3}\right)$ asymmetric and symmetric modes are computed as $2972,2901 \mathrm{~cm}^{-1}$ for B3LYP, and 2951, $2880 \mathrm{~cm}^{-1}$ for B3PW91. The CC ring stretching mode is computed as $1568 \mathrm{~cm}^{-1}$ for B3LYP and $1565 \mathrm{~cm}^{-1}$ for B3PW91. This mode in FT-IR was observed at $1558 \mathrm{~cm}^{-1}$ (Karaağaç et al., 2017). 


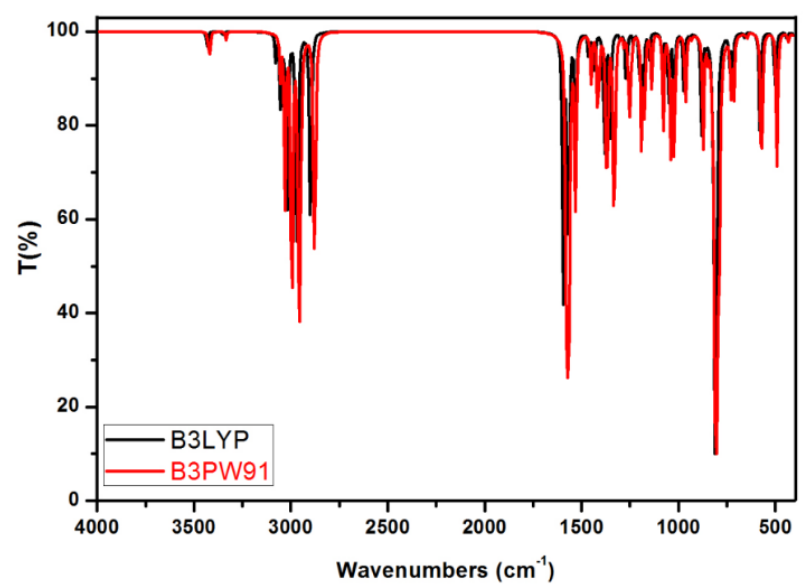

Figure 2 Calculated IR spectrum of 4-(1-aminoethyl)pyridine

The $(\mathrm{CH})_{R}$ in-plane bending vibration of 4-(1-aminoethyl)pyridine is computed as $1462 \mathrm{~cm}^{-1}$ for B3LYP level and $1449 \mathrm{~cm}^{-1}$ for B3PW91 level. This peak of the 4aepy molecule appears at $1442 \mathrm{~cm}^{-1}$. The in-plane $\mathrm{CH}_{3}$ bending vibration is calculated as $1429 \mathrm{~cm}^{-1}$ for B3LYP level and $1407 \mathrm{~cm}^{-1}$ for B3PW91 level. The $(\mathrm{CH})_{\mathrm{R}}$ out-of-plane bending vibration of the 4aepy molecule is observed at $1386 \mathrm{~cm}^{-1}$ experimentally and computed at $1382 \mathrm{~cm}^{-1}$ for DFT/ B3LYP and $1369 \mathrm{~cm}^{-1}$ for DFT/ B3PW91. The $(\mathrm{CH})_{\mathrm{R}}$ out-of-plane bending mode is computed to be $962 \mathrm{~cm}^{-1}$ and $953 \mathrm{~cm}^{-1}$ for B3LYP and B3PW91 levels. In pyridine and substituted pyridines, the ring breathing mode is near $995 \mathrm{~cm}^{-1}$ (Topaçlı et al., 1999; Vural et al., 2016). The ring breathing mode of 4-(1-aminoethyl)pyridine is calculated at $971 \mathrm{~cm}^{-1}$ and $953 \mathrm{~cm}^{-1}$ for B3LYP and B3PW91 levels. It can be said that DFT/B3LYP-calculated frequencies are in good agreement with the experimental values (Karaağaç et al., 2017; Vural et. al., 2019) of the similar compounds.

Table 2 Calculated IR frequencies of 4-(1-aminoethyl)pyridine

\begin{tabular}{|l|c|c|c|}
\hline & 4aepy* & B3LYP & B3PW91 \\
\hline$v_{a s}\left(\mathrm{NH}_{2}\right)$ & 3362 & 3432 & 3420 \\
\hline$v_{s}\left(\mathrm{NH}_{2}\right)$ & 3292 & 3349 & 3334 \\
\hline$v(\mathrm{CH})_{\mathrm{R}}$ & 3072 & 3077 & 3053 \\
\hline$v(\mathrm{CH})_{\mathrm{R}}$ & 3031 & 3050 & 3030 \\
\hline$v(\mathrm{CH})_{\mathrm{R}}$ & & 3021 & 2997 \\
\hline$v(\mathrm{CH})_{\mathrm{R}}$ & 2993 & 3018 & 2994 \\
\hline$v_{a s}\left(\mathrm{CH}_{3}\right)$ & & 2972 & 2951 \\
\hline$v_{s}\left(\mathrm{CH}_{3}\right)$ & & 2901 & 2880 \\
\hline$\beta\left(\mathrm{NH}_{2}\right)$ & 1605 & 1595 & 1575 \\
\hline$v\left(\mathrm{CC}_{\mathrm{R}}\right.$ & 1558 & 1568 & 1565 \\
\hline$\beta\left(\mathrm{CH}_{\mathrm{R}}\right.$ & 1442 & 1462 & 1449 \\
\hline$\beta\left(\mathrm{CH}_{3}\right)$ & & 1438 & 1416 \\
\hline$\beta\left(\mathrm{CH}_{3}\right)$ & & 1429 & 1407 \\
\hline$\beta(\mathrm{CH})$ & 1386 & 1382 & 1369 \\
\hline$\gamma\left(\mathrm{CH}_{3}\right)$ & & 1349 & 1327 \\
\hline $\mathrm{RB}(p y)$ & $807-1000$ & 971 & 965 \\
\hline$\gamma\left(\mathrm{CH}_{\mathrm{R}}\right.$ & & 962 & 953 \\
\hline$\gamma\left(\mathrm{NH}_{2}\right)$ & & 811 & 806 \\
\hline
\end{tabular}




\subsection{Electronic properties}

The UV-vis spectral data for the gas phase and solvent of 4-(1-aminoethyl)pyridine were estimated using two different DFT functional. The solvent effect was computed by using TDDFT (B3LYP and B3PW91) method and IEF-PCM model employing 6-311+G (d, p) basis set. The electronic spectral data of 4-(1-aminoethyl)pyridine are tabulated in Table 3, by using the Swizard program (Gorelsky, 2010). The B3LYP and B3PW91 hybrid functionals with 6$311+\mathrm{G}(\mathrm{d}, \mathrm{p})$ basis set were also used to calculate the chemical hardness $(\eta)$, softness $(s)$, electronegativity $(\chi)$, and electrophilicity index $(w)$ in the gas phase.

The calculated electronic spectrum of 4-(1-aminoethyl)pyridine showed different absorption maxima in the gas phase and water. According to TD-DFT/B3LYP/6-311+G (d,p) calculations (Table 3), the absorption maxima correspond to the electronic transitions from the $\mathrm{HOMO}(\mathrm{H}) \rightarrow \mathrm{LUMO}(\mathrm{L})(53 \%)$ and $\mathrm{HOMO}(\mathrm{H}) \rightarrow \mathrm{LUMO}(\mathrm{L})(67 \%)$. These bands are predicted as $\pi \rightarrow \pi^{*}$ transitions. For the compound, the highest wavelength band is computed as $256 \mathrm{~nm}(f$ $=0.0040$ ) for B3LYP level in the gas phase. The corresponding value is calculated at $246 \mathrm{~nm}$ $(f=0.0087)$ in the water. It is seen that the electronic transition wavelengths obtained at the gas phase are higher than the water solution. The calculated electronic transitions of 4-(1aminoethyl)pyridine calculated by the B3PW91 functional are found to be very close to the calculations made with the B3LYP functional

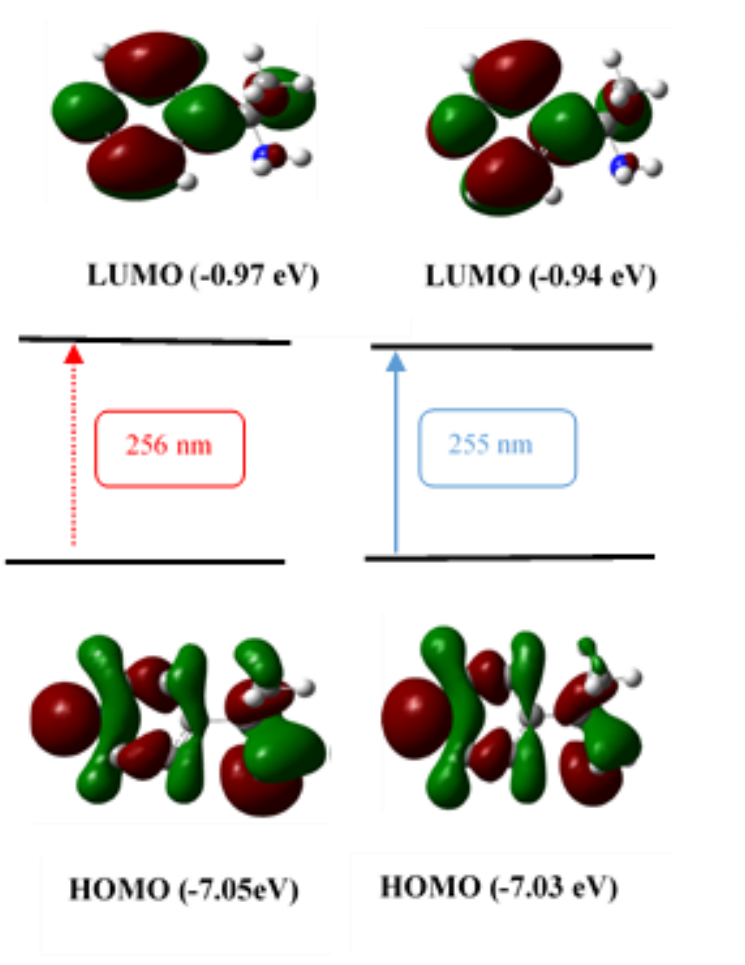

Figure 3. The FMOs of 4-(1-aminoethyl)pyridine by using the B3LYP and B3PW91 levels in the gas phase.

The HOMO and the LUMO have termed frontier molecular orbitals (FMOs). The energy gap $(\Delta \mathrm{E})$ between FMOs determines the energy that is very important to calculate chemical 
reactivity parameters (Vural et al., 2019). Figure 3 displays the energies of the FMOs for 4-(1aminoethyl)pyridine.

Table 3. Calculated electronic transitions for 4-(1-aminoethyl)pyridine with the TD-DFT method

\begin{tabular}{|c|c|c|c|c|}
\hline \multicolumn{2}{|c|}{$\begin{array}{l}\text { TD-DFT/ } \\
\text { IEF-PCM }\end{array}$} & $\lambda(\mathrm{nm})$ & $\begin{array}{c}\text { osc. } \\
\text { strength }\end{array}$ & major contributions \\
\hline \multirow[t]{2}{*}{ B3LYP } & $\begin{array}{c}\text { gas } \\
\text { phase }\end{array}$ & $\begin{array}{l}256 \\
228 \\
187 \\
185 \\
180\end{array}$ & $\begin{array}{l}0.0040 \\
0.0269 \\
0.0252 \\
0.1124 \\
0.1708\end{array}$ & $\begin{array}{l}\mathrm{H} \rightarrow \mathrm{L}(53 \%) \\
\mathrm{H}-1 \rightarrow \mathrm{L}(53 \%) \\
\mathrm{H}-1 \rightarrow \mathrm{L}+3(26 \%) \\
\mathrm{H}-3 \rightarrow \mathrm{L}+1(43 \%) \\
\mathrm{H}-3 \rightarrow \mathrm{L}+1(18 \%)\end{array}$ \\
\hline & water & $\begin{array}{l}246 \\
224 \\
185 \\
183 \\
181 \\
\end{array}$ & $\begin{array}{l}0.0087 \\
0.0308 \\
0.0466 \\
0.3895 \\
0.4293 \\
\end{array}$ & $\begin{array}{l}\mathrm{H} \rightarrow \mathrm{L}(67 \%) \\
\mathrm{H} \rightarrow \mathrm{L}+1(55 \%) \\
\mathrm{H}-2 \rightarrow \mathrm{L}+2(78 \%) \\
\mathrm{H}-1 \rightarrow \mathrm{L}+1(28 \%) \\
\mathrm{H} \rightarrow \mathrm{L}+4(19 \%)\end{array}$ \\
\hline \multirow{2}{*}{ B3PW91 } & $\begin{array}{c}\text { gas } \\
\text { phase }\end{array}$ & $\begin{array}{l}255 \\
226 \\
185 \\
180 \\
178\end{array}$ & $\begin{array}{l}0.0040 \\
0.0247 \\
0.0071 \\
0.1931 \\
0.1853\end{array}$ & $\begin{array}{l}\mathrm{H} \rightarrow \mathrm{L}(83 \%) \\
\mathrm{H}-2 \rightarrow \mathrm{L}(66 \%) \\
\mathrm{H}-2 \rightarrow \mathrm{L}+2(84 \%) \\
\mathrm{H}-2 \rightarrow \mathrm{L}+1(19 \%) \\
\mathrm{H}-1 \rightarrow \mathrm{L}+4(21 \%)\end{array}$ \\
\hline & water & $\begin{array}{l}246 \\
228 \\
195 \\
181 \\
179 \\
\end{array}$ & $\begin{array}{l}0.0089 \\
0.0112 \\
0.0395 \\
0.4528 \\
0.6549 \\
\end{array}$ & $\begin{array}{l}\mathrm{H} \rightarrow \mathrm{L}(64 \%) \\
\mathrm{H} \rightarrow \mathrm{L}+1(65 \%) \\
\mathrm{H} \rightarrow \mathrm{L}+2(82 \%) \\
\mathrm{H}-3 \rightarrow \mathrm{L}+1(40 \%) \\
\mathrm{H}-2 \rightarrow \mathrm{L}+1(26 \%)\end{array}$ \\
\hline
\end{tabular}

As given in Table 4, the I and A parameters of 4-(1-aminoethyl)pyridine are calculated by the DFT/B3LYP method are $7.05 \mathrm{eV}$ and $0.97 \mathrm{eV}$, respectively. The corresponding parameters are computed at $7.03 \mathrm{eV}$ and $0.94 \mathrm{eV}$ for B3PW91 level. The $\eta$ value is calculated at $3.04 \mathrm{eV}$ for B3LYP level and $2.95 \mathrm{eV}$ for B3PW91 level. The $s$ value is calculated at $0.16 \mathrm{eV}$ for the twohybrid functionals. The $w$ value is computed at $2.64 \mathrm{eV}$ for B3LYP level and $2.60 \mathrm{eV}$ for B3PW91 level. The very low chemical softness value of the title molecule indicates that it is theoretically non-toxic (Siddiqui and Javed, 2021). The $\Delta \mathrm{E}$ is found at $6.08 \mathrm{eV}$ for B3LYP level and $6.09 \mathrm{eV}$ for B3PW91 level. The chemical reactivity parameters computed by the B3LYP and B3PW91 methods are close to each other.

Table 4. Calculated FMOs analysis of 4-(1-aminoethyl)pyridine and related properties obtained by the two different DFT methods in the gas phase.

\begin{tabular}{|l|c|c|}
\hline Parameters (eV) & B3LYP & B3PW91 \\
\hline $\mathrm{E}_{\mathrm{HOMO}}$ & -7.05 & -7.03 \\
\hline $\mathrm{E}_{\mathrm{LUMO}}$ & -0.97 & -0.94 \\
\hline$\Delta \mathrm{E}=\mathrm{E}_{\mathrm{LUMO}}-\mathrm{E}_{\mathrm{HOMO}}$ & 6.08 & 6.09 \\
\hline $\mathrm{I}$ & 7.05 & 7.03 \\
\hline $\mathrm{A}$ & 0.97 & 0.94 \\
\hline$\chi$ & 4.01 & 3.98 \\
\hline$\eta$ & 3.04 & 3.04 \\
\hline$s$ & 0.16 & 0.16 \\
\hline$w$ & 2.64 & 2.60 \\
\hline
\end{tabular}




\section{Conclusions}

In the present paper, the vibrational frequencies and global reactivity descriptors of 4-(1aminoethyl)pyridine have been investigated by using the hybrid functional (B3LYP and B3PW91) of the DFT. The vibrational wavenumbers obtained by the B3LYP hybrid functional are in good agreement with that from FT-IR. The influence of the solvent on the electronic spectral properties of 4-(1-aminoethyl)pyridine is estimated using two different DFT hybrid functional. According to the results of the time-dependent DFT calculation, the electronic spectra of 4-(1-aminoethyl)pyridine showed different absorption maxima in the gas phase and water. The electronic transitions of 4-(1-aminoethyl)pyridine calculated by the B3PW91 functional are found to be very close to the calculations made with the B3LYP functional. The $\Delta \mathrm{E}$ is found to be $6.08 \mathrm{eV}$ which suggests that the molecule bioactive in nature. The comparatively low energy gap between FMOs suggests that the charge transfer may occur within 4-(1-aminoethyl)pyridine. The molecule and its complexes may be used as reagents or precursors in many fields such as physics, chemistry, pharmacology, and materials science.

\section{References}

Bhatt, A. H., Parekh, M. H., Parikh, K. A., \& Parikh, A .R. (2001). Synthesis of pyrazolines and cyanopyridines as potential antimicrobial agents. Indian Journal of. Chemistry., 40(6), $57-$ 61 .

Dennington, R. (2009). GaussView Version 5, Roy, Todd Keith and John Millam, Semichem Inc., Shawnee Mission K.S.

Dosh,i R., Kagathara, P.,\&, Parekh H. (1999). Synthesis and biological evaluation of some novel isoxazoles and cyanopyridines, a new class of potential anti-tubercular agents. Ind. $J$. Chem., 38, 348-352.

Dubey, P. K., Chowdary, K. S., Ramesh, B., \& Prasada, Reddy P. V. V. (2010). Na2S2O4: A Versatile Reagent for the One-Pot Synthesis of 2-Aryl-1H-imidazo[4,5-c]pyridines from 4Amino-3-nitropyridine and Aldehydes via Reductive Cyclization. Synthetic Communications, 40, 697-708. https://doi.org/10.1080/00397910903011345

Dursun, K. D., Kürkçüoğlu ,G. S., Şenyel, M., \& Şahin, O. (2017). Synthesis, spectroscopic, thermal and structural properties of 4-(2-aminoethyl)pyridinium tetracyanometallate(II) complexes. Journal of Molecular Structure, 1136, 281-287. https://doi.org/10.1016/j.molstruc.2017.02.013

Frisch, M.J. et al., 2009. Gaussian 09, Revision A.1, Gaussian, Inc., Wallingford CT.

Gorelsky, S. I., 2010. SWizard Program Revision 4.5 University of Ottawa, Ottawa, Canada, http://www.sg.chem.net/ (2010).

Hishmat, O. H., Galil, F. M. A., \& Farrag, D. S. (1990). Synthesis and antimicrobial activity of new benzofuranylpyridine derivatives. Pharmazie, 45, 793-795.

Huang, R., Wallqvist, A., \& Covell, D. G. (2005). Anticancer metal compounds in NCI's tumorscreening database: putative mode of action. Biochem. Pharmacol., 69(7), 10091039.https://doi.org/10.1016/j.bcp.2005.01.001 
Karaağaç, D., Kürkçüoğlu, G. S., Şenyel, M., \& Hökelek, T. (2019). Syntheses, crystal structures, spectroscopic properties and thermal decompositions of one dimensional coordination polymers with 4-(2-aminoethyl)pyridine and cyanide ligands: $[\mathrm{M}(\mu-$

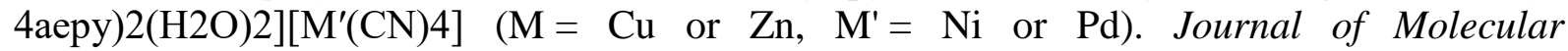
Structure,1176, 641-649. https://doi.org/10.1016/j.molstruc.2018.08.110

Karaağaç, D., Kürkçüoğlu, G. S., Şenyel, M., \& Hökelek, T. (2017). Syntheses, structural characterization and spectroscopic studies of cadmium(II)-metal(II) cyanide complexes with 4(2-aminoethyl)pyridine. Journal of Molecular Structure,1130, 80-88, https://doi.org/10.1016/j.molstruc.2016.09.089

Karaağaç, D., Kürkçüoğlu, G. S., Şenyel, M., \& Şahin, O. (2017). Synthesis, spectroscopic, thermal and structural properties of 4-(2-aminoethyl)pyridinium tetracyanometallate(II) complexes. Journal of Molecular Structure, 1136, 281-287. https://doi.org/10.1016/j.molstruc.2017.02.013

Keogh, M., Sedehizadeh, S., \& Maddison, P. C. (2011). Treatment for Lambert-Eaton myasthenic syndrom. Database of Systematic Reviews, 2, 1-21. https://doi.org/10.1002/14651858.CD003279.pub3

Lee, C., Yang, W., \& Parr, R.G. (1988). Development of the Colle-Salvetti correlation-energy formula into a functional of the electron density. Phys. Rev., $B$ 37, 785789.https://doi.org/10.1103/PhysRevB.37.785

Middleton, R. W. \& Wimberley, D. G. (1980). Synthesis of 2-amino-3-benzoylphenylacetic acid. J. Heterocycl. Chem. 17(8), 1663-1664.

Patrick G. L. and Kinsmar O. S. (1996). Synthesis and antifungal activity of novel aza-d-homosteroids, hydroisoquinolines, pyridines and dihydropyridines. J. Med. Chem., 31, 615624. https://doi.org/10.1016/0223-5234(96)89557-2

Perdew, J. P., Burke, K., \& Wang, Y. (1996). Generalized gradient approximation for the exchange-correlation hole of a many-electron system. Phys. Rev. B 54, 16533-16539. https://doi.org/10.1103/PhysRevB.54.16533

Pizarro, A. M. \& Sadler, P. J. (2009). Unusual DNA binding modes for metal anticancer complexes. Biochimie, 91(10), 1198-211. https://doi.org/10.1016/j.biochi.2009.03.017.

Sankpal, U. T., Pius, H., Khan, M., Shukoor, M. I., Maliakal, P., Lee, C .M., Abdelrahim, M., Connelly, S. F., \& Basha, R. (2012). Environmental factors in causing human cancers: emphasis on tumorigenesis. Tumor Biol., 33 (5), 1265-1274. https://doi.org/10.1007/s13277-012-0413-4

Sedehizadeh, S., Keogh, M., \& Maddison, P. (2012). The Use of Aminopyridines in Neurological Disorders. Clinical Neuropharmacol, 35, 191-200. doi: 10.1097/WNF.0b013e31825a68c5

Siddiqui, N. \& Javed, S. (2021). Quantum computational, spectroscopic investigations on ampyra (4-aminopyridine) by dft/td-dft with different solvents and molecular docking studies. Journal of Molecular Structure,1224,129022.https://doi.org/10.1016/j.molstruc.2020.129021 
Smith, R. C. F., Emmen, H. H., Bertelsmann, F. W., Kulig, B. M., van Loenen, A. C., \& Polman, C. H. (1994). The effects of 4-aminopyridine on cognitive function in patients with multiple sclerosis: A pilot study. Neurology, 44(9), 1701- 1705. https://doi.org/10.1212/WNL.44.9.1701

Strupp, M., Teufel, J., Zwergal, A., Schniepp, R., Khodakhah, K., \& Feil, K. (2017). Aminopyridines for the treatment of neurologic disorders. Neurol Clin Pract.,7(1), 65-76. https://doi.org/10.1212/CPJ.0000000000000321

Szakacs, G., Paterson, J. K., Ludwig, J. A., Booth-Genthe, C., \& Gottesman, M. M. (2006). Targeting multidrug resistance in cancer. Nat. Rev. Drug Discov., 5, 219-234. https://doi.org/10.1038/nrd1984

Topaçl1, A. \& Bayarı, S. (1999).Urey-Bradley force field of 4-ethylpyridine. Spectrochimica Acta Part A: Molecular and Biomolecular Spectroscopy,55(7-8),1389-1394. https://doi.org/10.1016/S1386-1425(98)00302-3

Vural, H., Kara, M., \& İdil, Ö. (2016). Experimental and computational study of the structure and spectroscopic properties of 1',3'-Dihydrospiro[cyclohexane-1,2'-[2H]imidazo[4,5b]pyridine]. Journal of Molecular Structure,1125,662-670, https://doi.org/10.1016/j.molstruc.2016.07.065

Vural, H., Ozdogan, T., \& Orbay, M. (2019). DFT investigation of the electronic structure and nonlinear optic properties (NLO) of 3-amino-4-(Boc-amino)pyridine. Indian J Phys., 93, 11131122. https://doi.org/10.1007/s12648-019-01391-0 